\title{
Perancangan Water Level Control Menggunakan PLC Omron Sysmac C200H Yang Dilengkapi Software SCADA Wonderware InTouch 10.5
}

\author{
Indra Saputra, Lukmanul Hakim, Sri Ratna S \\ Jurusan Teknik Elektro Universitas Lampung \\ J1. Prof. Sumantri Brojonegoro No. 1 Bandar Lampung 35145 \\ indraelektrounila@gmail.com
}

\begin{abstract}
Abstrak
Feed water tank merupakan salah satu komponen pada boiler yang memiliki fungsi penting dalam menyuplai air ke boiler. Level air pada feed water tank harus tetap dijaga agar tidak terjadi kekosongan saat proses pengisian air ke boiler. Selama ini operator masih memantau secara langsung level air pada feed water tank. Sehingga diperlukan sistem otomasi water level control yang dapat membantu operator dalam mengontrol dan memantau level air pada feed water tank. Sistem otomasi water level control dikendalikan oleh PLC Omron Sysmac C200H dengan menggunakan panel push button yang terpasang pada plant atau juga dapat dikendalikan dan dimonitor melalui melalui PC menggunakan software SCADA Wonderware InTouch 10.5. Selain itu sistem otomasi menggunakan SCADA ini dilengkapi password sebagai pengaman dari orang yang tidak bertanggung jawab.
\end{abstract}

Kata kunci : PLC, SCADA, water level control, feed water tank

\begin{abstract}
Feed water tank is one component of the boiler system which has an important function in supplying water to the boiler. Water levels in feed water tank is must be maintaned to avoid emptiness at filling process to the boiler. Previously, the operator directly to monitors water level in the feed water tank. Therefore, a control mechanisem is required to help the operators to control and monitor the water level in the feed water tank autonomously. In this system, water level is controlled by PLC Omron C200H Sysmac using the push button panel attached to the plant or also can be controlled and monitored by PC using Wonderware InTouch 10.5. In addition, SCADA system is equipped with a password to secure from irresponsible people.
\end{abstract}

Key word : PLC, SCADA, water level control, feed water tank

\section{PENDAhuluan}

Boiler merupakan salah satu komponen utama sistem Pembangkitan Listrik Tenaga Uap (PLTU) pada PT Gunung Madu Plantations.

Boiler memiliki peralatan pendukung feed water tank yang berfungsi sebagai penyuplai air ke dalam boiler. Hal yang harus diperhatikan pada feed water tank adalah level air yang harus tetap dijaga pada level tertentu, karena jika air pada feed water tank kosong bisa berakibat fatal pada boiler yang dapat mengganggu proses produksi listrik. Selain itu, kendali air pada feed water tank masih dilakukan secara manual. Sehingga dibutuhkan sistem otomasi yang dapat membantu operator dalam mengontrol level air pada feed water tank.
Pada tugas akhir ini telah dibuat suatu sistem otomasi water level control yang diaplikasikan pada feed water tank menggunakan PLC Omron Sysmac C200H yang dilengkapi dengan sistem SCADA (Supervisory Control and Data Aqcuisition) menggunakan software Wonderware InTouch versi 10.5.

\section{TINJAUAN PUSTAKA}

\subsection{Sistem Kendali}

Sistem kendali adalah suatu sistem yang keluarannya sistem dikendalikan pada suatu nilai tertentu atau untuk mengubah beberapa ketentuan yang telah ditetapkan oleh masukan ke sistem. Sistem kendali dibagi menjadi dua yaitu sistem kendali loop terbuka dan sistem kendali loop tertutup[1]. 


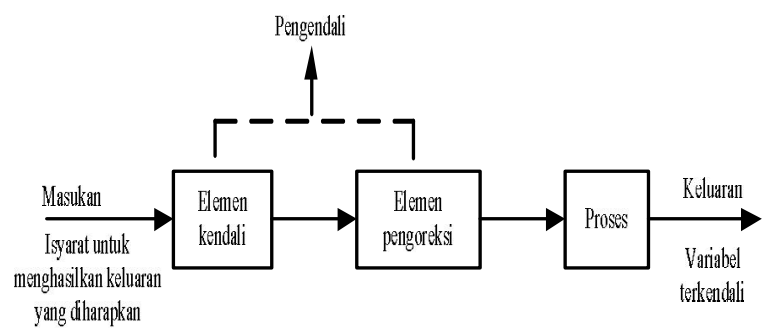

Gambar 1. Subsistem-subsistem pada sebuah sistem kendali loop terbuka

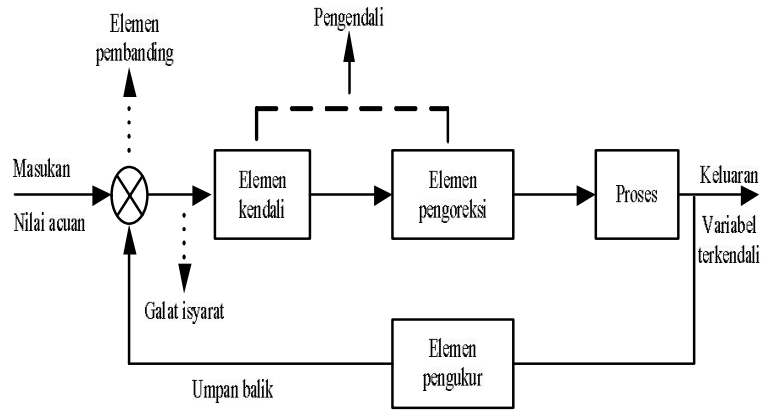

Gambar 2. Subsistem-subsistem pada sebuah sistem kendali loop tertutup

\subsection{Programmable Logic Controller (PLC)}

Programmable Logic Controller (PLC) adalah sebuah alat yang digunakan untuk menggantikan rangkaian sederatan relai yang dijumpai pada sistem kendali konvensional. Hanya dengan mengeksekusi program yang tersimpan dalam memori, PLC dapat memonitor status dari suatu sistem berdasarkan sinyal input yang masuk pada PLC[2][3].

PLC merupakan sistem mikrokontroler khusus untuk industri, artinya seperangkat software dan hardware yang diadaptasi untuk keperluan aplikasi dalam dunia industri. Secara umum PLC memiliki bagian-bagian yang sama dengan komputer maupun mikrokontroler, yaitu CPU, Memori dan I/O. Susunan komponen PLC dapat dilihat pada gambar berikut[4]:

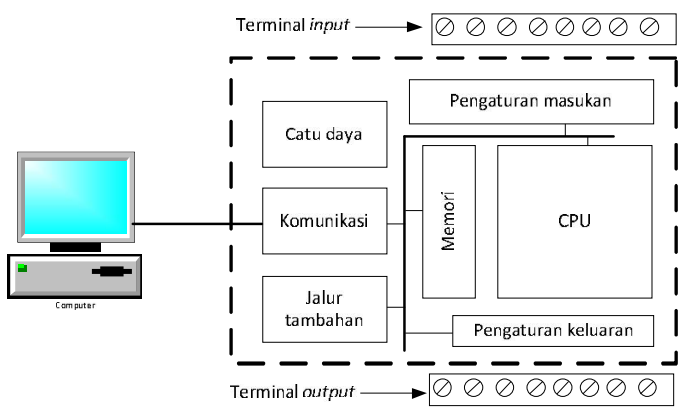

Gambar 3. Elemen-elemen dasar PLC

\subsection{SCADA (Supervisory Control and Data Acquistion)}

SCADA (Supervisory Control and Data Acquistion) adalah sistem yang melakukan pengawasn (supervisory), pengendalian (control), dan akuisisi data (data acquistion) terhadap plant.

Salah satu software yang banyak digunakan adalah Wonderware. Software utama yang digunakan dalam sistem SCADA adalah InTouch yang berfungsi sebagai Human Machine Interface (HMI). Secara sederhana HMI berfungsi sebagai "jembatan" bagi manusia (operator) untuk memahami proses yang terjadi pada plant. Sebuah HMI yang baik akan memiliki struktur yang jelas dan lengkap seperti yang digambarkan pada struktur HMI di bawah ini[5] :

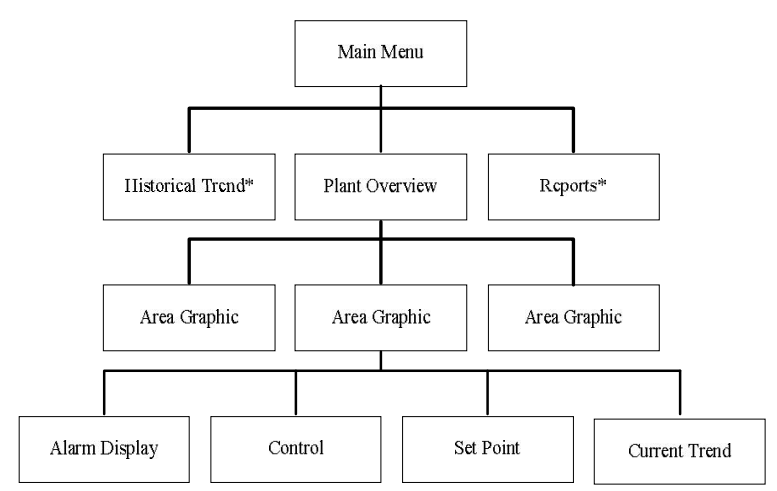

*Tidak bisa dibuat hanya dengan menggunakan Wonderware InTouch saja.

Gambar 4. Struktur HMI

\subsection{Motor Induksi Satu Fasa}

Motor induksi satu fasa memiliki dua belitan stator, yaitu belitan utama (belitan $\mathrm{U}_{1}-\mathrm{U}_{2}$ ) dan belitan fasa bantu (belitan $\left.Z_{1}-Z_{2}\right)[6]$.

Belitan bantu $Z_{1}-Z_{2}$ pertama dialiri arus $I_{\text {bantu }}$ menghasilkan fluks magnet $\Phi$ tegak lurus, beberapa saat kemudian belitan utama $\mathrm{U}_{1}-\mathrm{U}_{2}$ dialiri arus utama $\mathrm{I}_{\text {utama }}$ yang bernilai positif. Hasilnya adalah medan magnet yang bergeser sebesar $45^{\circ}$ dengan arah berlawanan jarum jam. Kejadian ini berlangsung terus sampai satu siklus sinusoidal, sehingga menghasilkan medan magnet yang berputar pada belitan statornya. Medan putar stator akan memotong belitan rotor, sehingga menghasilkan tegangan induksi. 
Interaksi antara medan putar stator dan medan magnet rotor akan menghasilkan torsi putar pada rotor.

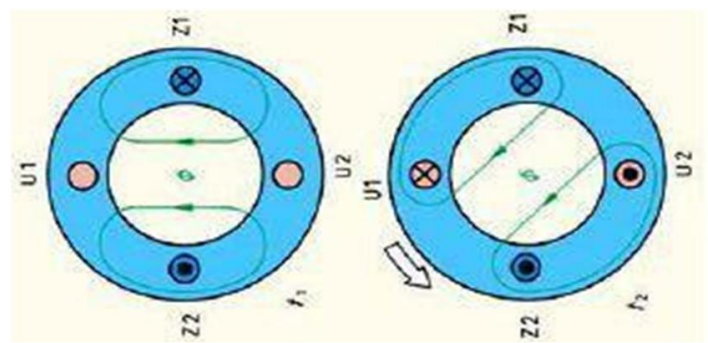

Gambar 5. Medan magnet pada stator motor induksi satu fasa

\subsection{Level Controller}

Level controller berfungsi untuk melakukan kendali terhadap ketinggian air di dalam tangki dengan jalan mengirimkan output sinyal kepada kendali motor. Salah satu contoh level controller adalah Floatless Level Switch Omron 61F-GP$\mathrm{N}[7]$.

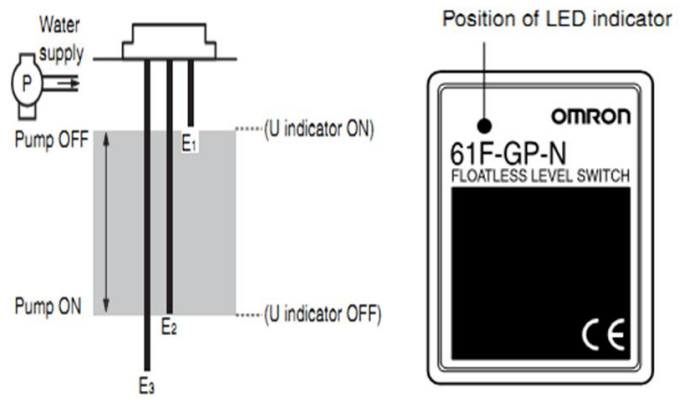

Gambar 6. Omron 61F-GP-N

Omron 61F-GP-N memiliki 11 piranti pin dan bekerja pada tegangan supply 220 VAC. Pin 3 dan 9 merupakan terminal power supply dengan tegangan 220 VAC. Untuk pin 4 dan 5 digunakan sebagai elektrode $\mathrm{E}_{3}$ dan $\mathrm{E}_{1}$. Pin 1, 10, dan 11 adalah kontak output. Sedangkan pin 6, 7, dan 8 merupakan kontal relai.

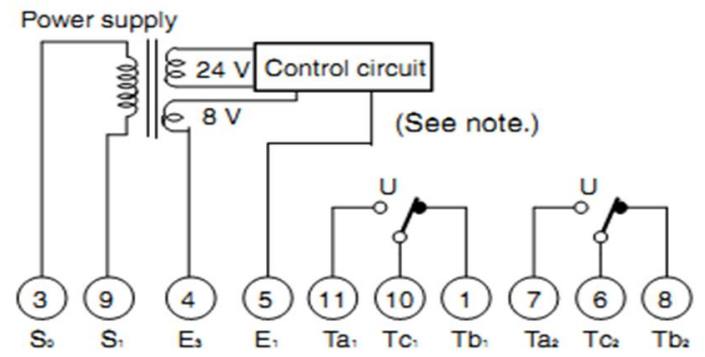

Gambar 7. Internal circuit diagram Omron 61F-GP-N

\subsection{Push Button}

Push button adalah saklar yang beroperasi dengan cara ditekan. Pada push button terdapat knop yang berfungsi sebagai area penekan yang biasanya berwarna merah dan pada bagian bawahnya terdapat terminal yang berupa kontak normally open, di mana kontak akan menutup bila tombol ditekan dan normally close, di mana kontak akan terbuka bila tombol ditekan[4].

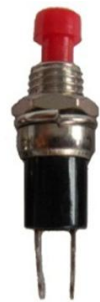

Gambar 8. Push button

\subsection{Relay Omron MY4N}

Relay MY4N memiliki 8 kontak yaitu 4 normally open dan 4 normally close. Pin 13 dan 14 adalah coil 220 VAC. Prinsip kerja dari relai ini adalah ketika coil mendapatkan arus listrik (energized), maka akan timbul elektromagnetik yang akan menggerakkan kontak, dimana kontak yang awalnya normally close (NC) akan menjadi normally open (NO). Arus beban maksimum yang dapat dipikul oleh relay MY4N ini adalah 5 $\mathrm{A}[8]$.
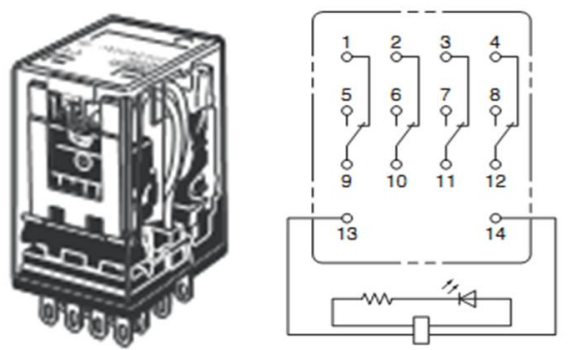

Gambar 9. Relay Omron MY4N

\subsection{Pengisian dan Pengosongan Tangki}

\subsubsection{Pengisian Tangki}

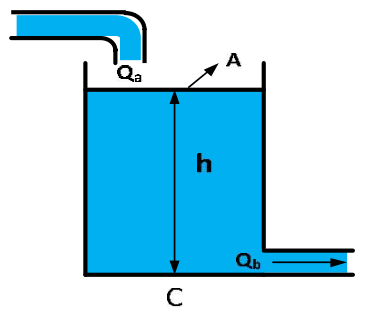

Gambar 10. Model pengisian tangki 
Tinggi tangki dimisalkan sebagai sebuah kapasitansi, laju perubahan volume (V) di dalam sebuah tangki $\left(\frac{\mathrm{dv}}{\mathrm{dt}}\right)$ adalah sama dengan beda laju volumetrik air yang masuk $\mathrm{Q}_{\mathrm{a}}$ dengan laju volumetrik yang keluar $\mathrm{Q}_{\mathrm{b}}$ sehingga bila ditulis dalam persamaan matematisnya[1] :

$$
\begin{aligned}
& Q_{a-}-Q_{b}=\left(\frac{d v}{d t}\right) \\
& V=A \cdot h \\
& Q_{a}-Q_{b}=\left(\frac{d(A . h)}{d t}\right) \\
& Q_{a}-Q_{b}=\left(\frac{A \cdot d h}{d t}\right)
\end{aligned}
$$

Dengan mengintegrasi persamaan 2.3, diperoleh persamaan umum untuk pengisian tangki :

$$
\left(Q_{a}-Q_{b}\right) t+C=A \cdot h
$$

Diketahui bahwa ketinggian mula-mula air pada tangki 1 (feed water tank) dan 2 (boiler) adalah $0 \mathrm{~cm}(\mathrm{~h}(0)=0 \mathrm{~cm})$, diameter (d) tangki 1 dan 2 masing-masing adalah $22 \mathrm{~cm}$ dan $13 \mathrm{~cm}$, maka diperoleh persamaan khusus dari persamaan 2.4:

$$
\begin{aligned}
& \left(Q_{1}-Q_{2}\right) t=A_{1} \cdot h_{1} \\
& t=\frac{A_{1} \cdot h_{1}}{\left(Q_{1}-Q_{2}\right)} \\
& \left(Q_{3}-Q_{4}\right) t=A_{2} \cdot h_{2} \\
& t=\frac{A_{2} \cdot h_{2}}{\left(Q_{2}-Q_{3}\right)}
\end{aligned}
$$

Keterangan :

$\mathrm{Q}_{1}=$ Laju volumetrik masuk pada tangki 1

$\mathrm{Q}_{2}=$ Laju volumetrik keluar pada tangki 1

$\mathrm{Q}_{3}=$ Laju volumetrik masuk pada tangki 2

$\mathrm{Q}_{4}=$ Laju volumetrik keluar pada tangki 2

$\mathrm{A}_{1}=$ Luas penampang tangki 1

$\mathrm{A}_{2}=$ Luas penampang tangki 2

$\mathrm{h}_{1}=$ Ketinggian cairan pada tangki 1

$\mathrm{h}_{2}=$ Ketinggian cairan pada tangki 2

\subsubsection{Pengosongan Tangki}

Pada saat pengosongan tangki, metode yang digunakan adalah dengan mengalirkan air yang ada di dalam suatu tangki dengan luas penampang B pada level ketinggian $\mathrm{h}(\mathrm{t})$ melalui sebuah lubang yang memiliki luas penampang $\mathrm{A}$ ke atmosfer atau udara[1].

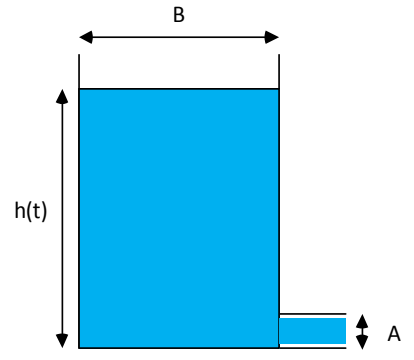

Gambar 11. Model pengosongan tangki

Air yang keluar memiliki suatu kecepatan, sehingga berdasarkan Hukum Torricelli :

$$
V(t)=0,6 \sqrt{2 g h(t)}
$$

Untuk mendapatkan suatu persamaan, diambil suatu hubungan penurunan level ketinggian air $\mathrm{h}(\mathrm{t})$ yang mengalir melalui lubang. Sehingga volume $\Delta \mathrm{V}$ air yang terjadi dalam waktu yang singkat $\Delta \mathrm{t}$ adalah :

$$
\Delta \mathrm{V}=\text { A.v. } \Delta \mathrm{t}
$$

$\mathrm{A}=$ Luas penampang lubang $\left(\mathrm{cm}^{2}\right)$

Nilai $\Delta \mathrm{V}$ harus sama dengan $\Delta \mathrm{V}^{*}$ pada suatu volume air di dalam tangki, sehingga:

$$
\Delta \mathrm{V}^{*}=-\mathrm{B} . \Delta \mathrm{h}
$$

$\mathrm{B}=$ Luas penampang tangki $\left(\mathrm{cm}^{2}\right)$

$\Delta \mathrm{h}$ merupakan penurunan level ketinggian $h(t)$. Tanda minus (-) muncul karena volume air yang ada dalam tangki menurun. Sehingga persamaan yang dapat diberikan dari $\Delta \mathrm{V}$ dan $\Delta \mathrm{V}^{*}$ adalah :

$$
\begin{aligned}
& \Delta V^{*}=\Delta V \\
& -B \Delta h=A \cdot v \cdot \Delta t \\
& \frac{\Delta \mathrm{h}}{\Delta \mathrm{t}}=-\frac{A}{B} \cdot v \\
& \frac{\Delta \mathrm{h}}{\Delta \mathrm{t}}=-0,6 \frac{A}{B} \cdot \sqrt{2 \cdot g \cdot h(t)} \\
& \frac{d h}{d t}=-0,6 \frac{A}{B} \sqrt{2 \cdot g \cdot h} \\
& \frac{d h}{d t}=-26,56 \frac{A}{B} \sqrt{h} \\
& \int \frac{d h}{\sqrt{h}}=\int-26,56 \frac{A}{B} d t \\
& 2 \sqrt{h}=-26,56 \frac{A}{B} t+c \\
& \sqrt{h}=-13,28 \frac{A}{B} t+\frac{c}{2}
\end{aligned}
$$


Dengan mengasumsikan $\frac{c}{2}=\mathrm{C}$, maka :

$$
h=\left(-13,28 \frac{A}{B} t+C\right)^{2}
$$

Diketahui bahwa ketinggian mula-mula air pada tangki 1 dan 2 adalah $18 \mathrm{~cm}(\mathrm{~h}(0)=18 \mathrm{~cm})$, diameter lubang pada tangki 1 dan 2 adalah 1,1 $\mathrm{cm}$, diameter (d) tangki 1 dan 2 masing-masing adalah $22 \mathrm{~cm}$ dan $13 \mathrm{~cm}$, sehingga didapat persamaan khusus dari persamaan 2.13 yaitu :

$$
\begin{aligned}
& h_{1}=(4,24-0,0332 t)^{2} \\
& h_{2}=(4,24-0,0951 t)^{2}
\end{aligned}
$$

Keterangan :

$\mathrm{h}_{1}=$ Ketinggian air pada tangki 1

$\mathrm{h}_{2}=$ Ketinggian air pada tangki 2

$\mathrm{t}$ = waktu pengosongan

\section{METODOLOGI PENELITIAN}

Penelitian ini merancang sebuah water level control yang dilengkapi dengan sistem SCADA menggunakan software Wonderware InTouch 10.5. Dalam proses penelitian, hal-hal yang dilakukan sebagai berikut:

1. Mengumpulkan pustaka yang akan digunakan pada penelitian sebagai bahan pembelajaran untuk menunjang keberhasilan penelitian,

2. Membuat miniatur water level control,

3. Membuat ladder diagram untuk water level contol dengan menggunakan $\mathrm{CX}$-One Programmer.

4. Membuat desain SCADA untuk water level control dengan menggunakan Wonderware InTouch 10.5.

5. Melakukan analisa terhadap sistem water level control

6. Perancangan sistem water level control selesai telah siap digunakan

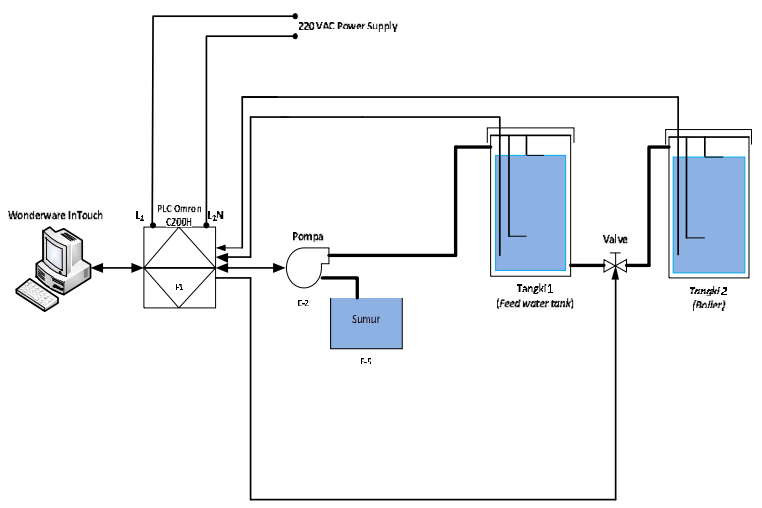

Gambar 11. Skema rancangan water level control

\section{HASIL DAN PEMBAHASAN}

\subsection{Hasil Desain Hardware}

Penelitian ini telah membuat watel level control yang diaplikasikan pada miniatur plant feed water tank. Water level control ini dikendalikan menggunakan PLC Omron Sysmac $\mathrm{C} 200 \mathrm{H}$ dan dimonitor oleh software SCADA Wonderware InTouch 10.5. Sistem dapat bekerja secara manual maupun otomatis. Selain itu, sistem dapat dikendalikan dengan menggunakan push button yang terpasang pada panel atau dengan menggunakan komputer yang dilengkapi dengan Software Wonderware InTouch.

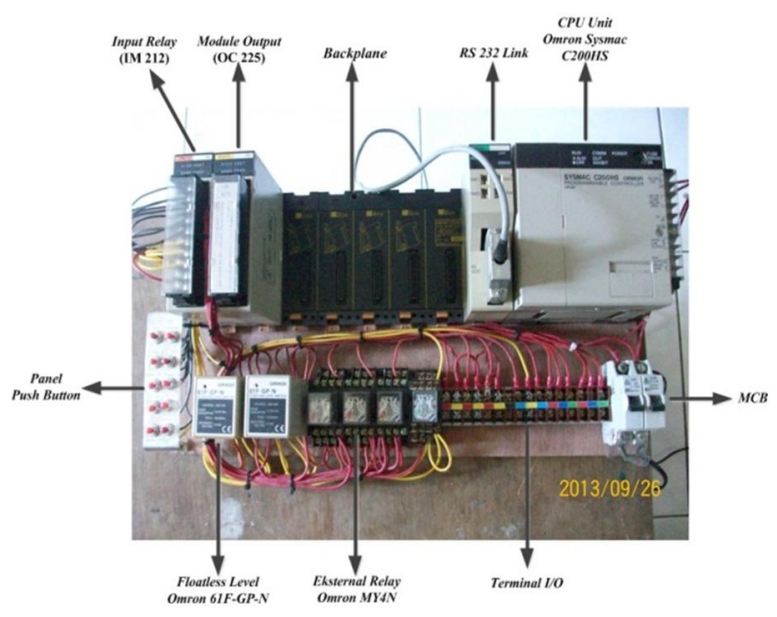

Gambar 12. Unit sistem kendali

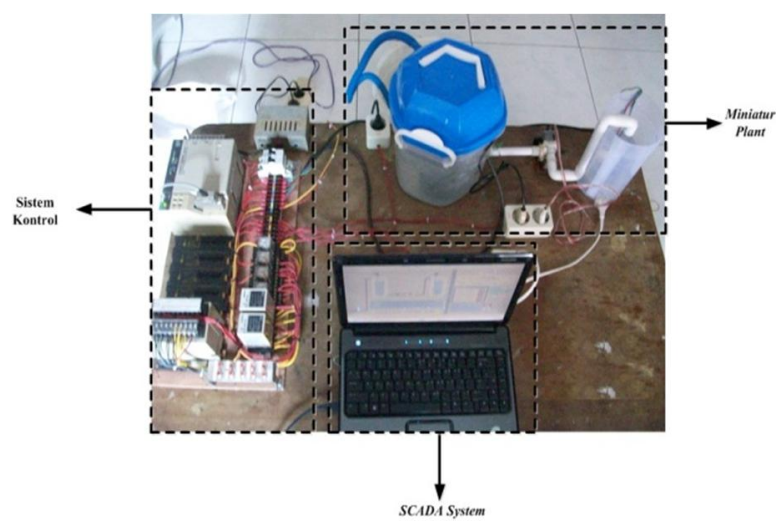

Gambar 13. Water Level Control dengan Software SCADA

\subsection{Hasil Desain Software}

Dalam desain software ini, program utama yang dipakai untuk membuat suatu perintah kerja plant yang dikendalikan menggunakan Omron SYSMAC $\mathrm{C} 200 \mathrm{H}$ adalah CX-Programmer v 8.0.Selain itu, software lain yang dipakai adalah 
Wonderware InTouch 10.5. Software ini digunakan sebagai interface suatu plant. Pada plant yang dibuat ini, plant dapat bekerja secara manual maupun otomatis. Selain itu, plant dibuat agar dapat dikendalikan dan dipantau menggunakan bantuan Wonderware InTouch atau dikendalikan melalui panel kontrol yang berupa push button yang terpasang pada plant.Berikut adalah hasil desain untuk ladder diagram dan interface plant pada Wonderware InTouch :

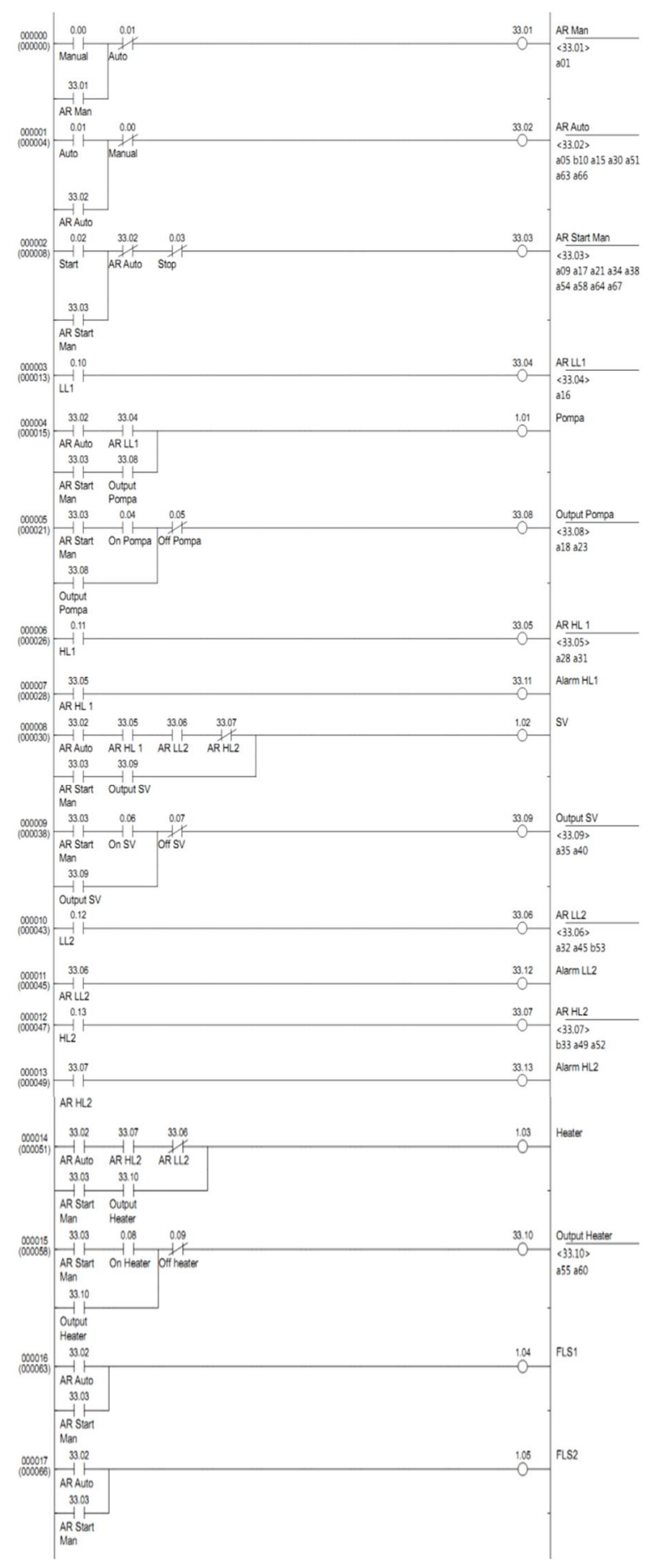

Gambar 14. Hasil desain ladder diagram

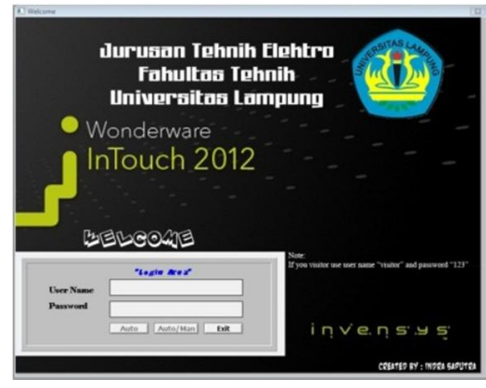

Gambar 15. Tampilan window welcome

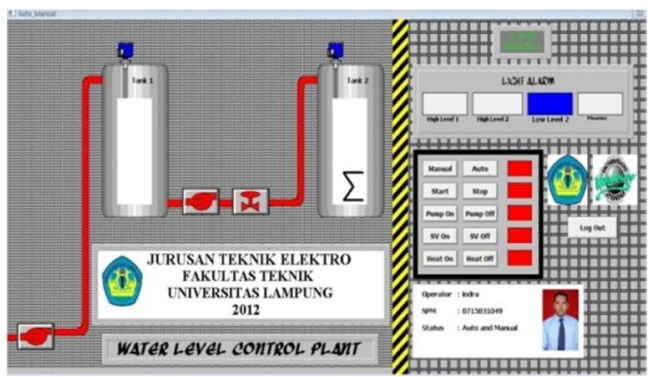

Gambar 16. Tampilan window Auto-Manual plant

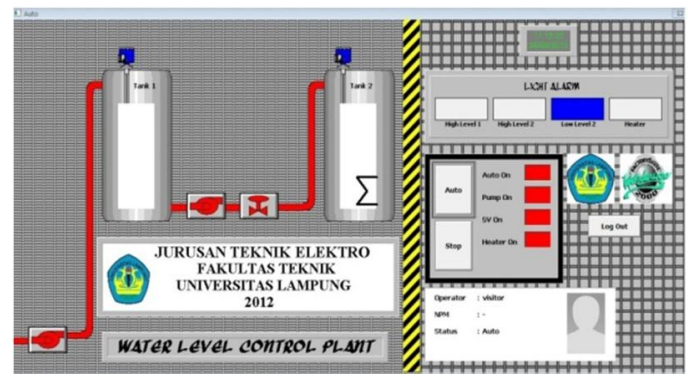

Gambar 17. Tampilan window Auto plant

\subsection{Pengujian Hasil Desain Software}

\subsubsection{Pengujian Program PLC}

Sebelum ladder diagram yang buat ditransfer ke dalam perangkat PLC Omron Sysmac C200H, langkah pertama yang harus dilakukan adalah melakukan compile program (Ctrl+F7). Tujuannya adalah untuk melihat program yang buat terdapat error atau tidak. Jika tidak ditemukan error maka program dapat ditransfer ke dalam PLC.

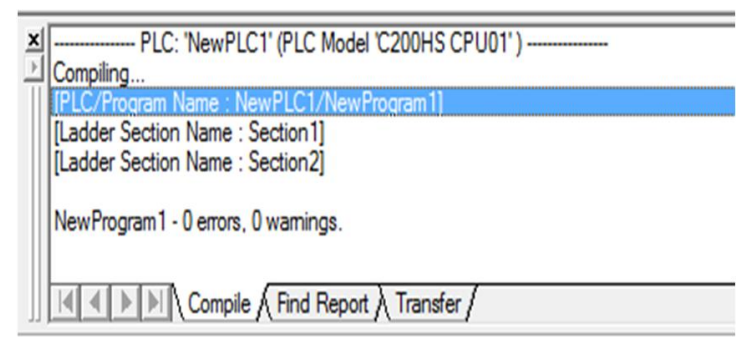

Gambar 17. Tampilan compile program PLC 


\subsubsection{Pengujian SCADA}

Dalam mengendalikan dan memantau kerja dari plant digunakan bantuan software Wonderware InTouch. Hal yang perlu diperhatikan adalah koneksi antara PLC sebagai kendali plant dan Wonderware InTouch sebagai antarmuka suatu plant. Untuk mengkoneksikan PLC dan Wonderware InTouch tersebut, digunakan I/O server Omron Host Link. Berikut adalah uji koneksi PLC dengan Wonderware InTouch.

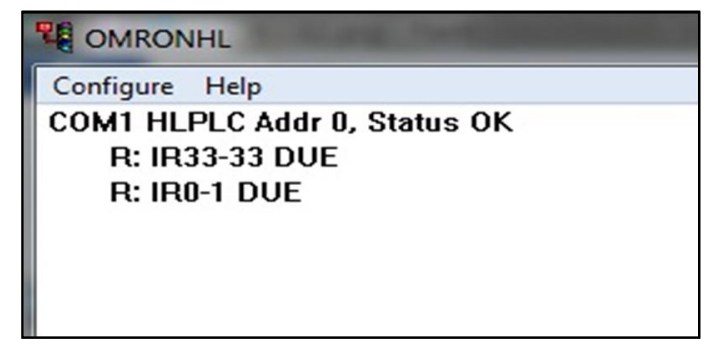

Gambar 18. Tampilan uji koneksi pada Omron Hostlink

\subsection{Pengujian Pengisian dan Pengosongan Tangki}

\subsubsection{Pengisian Tangki}

Dalam perhitungan diasumsikan faktor head statis atau jarak pompa dengan tangki pengisian diabaikan dalam perhitungan. Berikut adalah data hasil perhitungan dan pengukuran untuk tangki 1 dan 2:

Tabel 4.1 Data perhitungan dan pengukuran pada proses pengisian tangki 1 dan 2

\begin{tabular}{|c|c|c|c|c|}
\hline \multirow{2}{*}{ Level } & \multicolumn{2}{|c|}{ Tangki 1 } & \multicolumn{2}{c|}{ Tangki 2 } \\
\cline { 2 - 5 } Air (cm) & $\begin{array}{c}\text { Waktu } \\
\text { Hitung } \\
\text { (s) }\end{array}$ & $\begin{array}{c}\text { Waktu } \\
\text { Ukur } \\
\text { (s) }\end{array}$ & $\begin{array}{c}\text { Waktu } \\
\text { Hitung } \\
\text { (s) }\end{array}$ & $\begin{array}{c}\text { Waktu } \\
\text { Ukur } \\
\text { (s) }\end{array}$ \\
\hline 3 & 4,56 & 6,45 & 1,79 & 2,54 \\
\hline 6 & 9,12 & 15,56 & 3,68 & 4,32 \\
\hline 9 & 13,68 & 25,59 & 5,37 & 6,17 \\
\hline 12 & 18,23 & 35,99 & 7,16 & 8,87 \\
\hline 15 & 22,79 & 46,56 & 8,96 & 11,32 \\
\hline 18 & 27,35 & 58,38 & 10,74 & 14,01 \\
\hline
\end{tabular}

\subsubsection{Pengisian Tangki}

Dalam perhitungan diasumsikan bahwa valve dalam keadaan membuka $100 \%$ dan faktor ketinggian air terhadap lubang diabaikan atau lubang berada pada dasar tangki. Berikut adalah data hasil perhitungan dan pengukuran untuk tangki 1 dan 2 :

Tabel 4.2 Data perhitungan dan pengukuran pada proses pengosongan tangki 1 dan 2

\begin{tabular}{|c|c|c|c|c|}
\hline $\begin{array}{c}\text { Level } \\
\text { Air (cm) }\end{array}$ & $\begin{array}{c}\text { Waktu } \\
\text { Hitung } \\
\text { (s) }\end{array}$ & $\begin{array}{c}\text { Waktu } \\
\text { Ukur } \\
\text { (s) }\end{array}$ & $\begin{array}{c}\text { Waktu } \\
\text { Hitung } \\
\text { (s) }\end{array}$ & $\begin{array}{c}\text { Waktu } \\
\text { Ukur } \\
\text { (s) }\end{array}$ \\
\hline 15 & 11,05 & 16,16 & 3,86 & 5,2 \\
\hline 12 & 23,37 & 33,49 & 8,16 & 10,52 \\
\hline 9 & 37,34 & 53,35 & 13,04 & 16,35 \\
\hline 6 & 53 & 78,24 & 18,83 & 23,54 \\
\hline 3 & 75,6 & 121,99 & 26,37 & 48,49 \\
\hline
\end{tabular}

\section{SIMPULAN DAN SARAN}

\subsection{Kesimpulan}

Berdasarkan hasil penelitian yang telah dilakukan terhadap dapat diambil kesimpulan sebagai berikut:

1. Sistem otomasi menggunakan PLC Omron Sysmac $\mathrm{C} 200 \mathrm{H}$ yang dilengkapi software SCADA Wonderware InTouch 10.5 dapat bekerja dengan baik di mana hasil dari compile ladder diagram 0 errors dan koneksi Omron Host Link status Ok.

2. Software SCADA Wonderware InTouch 10.5, dapat mengendalikan dan memantau kerja suatu plant tanpa harus memantau langsung di lapangan.

\subsection{Saran}

Untuk pengembangan sistem water level control lebih lanjut maka dapat diberikan saran untuk menggunakan $\mathrm{I} / \mathrm{O}$ analog, di mana level air dapat dikendalikan dan tampilan animasi level control pada SCADA dapat dilihat secara real time.

\section{DAFTAR PUSTAKA}

[1] Sulistiyanti, Sri Ratna \& FX Arinto Setyawan. Dasar Sistem Kendali. Universitas Lampung. 2006.

[2] Putra, Agfianto E. PLC Konsep, Pemograman dan Aplikasi. Gava Media. 2007.

[3] Gupta, Himanish. Training Program On PLC. Seacom Engineering College. 2011. 
[4] Wicaksono, H. Programmable Logic Controller. Graha Ilmu. 2009.

[5] Wicaksono, H. SCADA Software dengan Wonderware InTouch. Graha Ilmu. 2012.

[6] Zuhal. Dasar Teknik Tenaga Listrik \& Elektronika Daya. Gramedia. 1995.

[7] OMRON. Floatless Level Controller 61F$G P-N$. OMRON Corporation. 2012. hal 1-4. $<$ http://www.ia.omron.com/data pdf/cat/61f -gp-n ds e 6 _ $1 \_$csm6.pdf?id=245> dipublikasi 6 November 2012.

[8] OMRON. General Purpose Relay MY4N. OMRON Corporation. 2013. hal 8-9. $<$ http://www.ia.omron.com/data_pdf/cat/my ds_e 4_1_csm59.pdf?id=948> dipublikasi 17 Juni 2013.

[9] Kreyszig, Erwin. Advanced Engineering Mathematics. John Wiley \& Sonc Inc. 2006. 